\title{
Corporate governance in state-owned enterprises. A systematic literature review: an international perspective
}

Radosław Miążek*† https://orcid.org/0000-0003-3685-6487

Abstract

*Jagiellonian University, Cracow, Poland. Email: radoslaw.miazek@doctoral.uj.edu.pl

Background. The state sector continues to play a significant role in the development of the global economy. Proper corporate governance is crucial to ensure the positive contribution of state-owned enterprises to the efficiency of the economy and its competitiveness. Despite the increasing importance of state-owned enterprises for the development of global gross domestic product and the quality of public services provided, research on corporate governance in state-owned enterprises is not widely represented in the world literature.

Research aims. This article provides a bibliographic analysis of the existing scientific work on corporate governance in stateowned enterprises. The aim of the analysis is to systematise the scientific output in this field, to demonstrate the scale of interest in this subject among researchers, and to indicate the predominant directions of research, taking into account their geographical origin.

Methodology. This study uses a systematic literature review.

Findings. The results of the research show that the existing scientific work in this field is insignificant in relation to the number of state-owned enterprises operating worldwide and their importance for the development of the global economy. Research by dominant research groups from the point of view of geography has shown that there is a clear variation in the dominant direction of research on corporate governance in state-owned enterprises, which is an indication of the different interests of researchers in different geographic areas. Analysing the factors underlying the differentiation just described could provide an incentive for further empirical research in this area.

Keywords

corporate governance, state-owned enterprise, literature review

\section{INTRODUCTION}

State-owned enterprises continue to play an important role in the global economy. Despite the privatisation processes in place, they are still key players in the economies of many countries. In the last 20 years, the share of state-owned enterprises among the 2,000 largest companies in the world has doubled to $20 \%$. It is estimated that the total assets of state-owned enterprises in the world amount to approximately US\$45 trillion, which is equivalent to half of the global gross domestic product (GDP; International Monetary Fund, 2020).

According to Organisation for Economic Co-operation and Development (OECD) data, the strong majority of state-owned enterprises are registered in China, where the state owns more than 51,000 such entities. Other countries with the largest number of state-owned enterprises are Hungary (370), India (270), Brazil (134), Czech Republic (133), Lithuania (128), Poland (126), and Slovakia (113; OECD, 2017).

Maintaining state control over key companies for the economy is a kind of compromise between productivity and broader social and economic interests and is characteristic of both emerging economies and many developed countries (Pekao, 2020). From this point of view, the goals set for state-owned companies are different from those for commercial companies. Whereas commercial companies are mainly focused on generating profit for their shareholders, state-owned entities fulfil, apart from economic goals, other specific social objectives, such as providing jobs, serving the public interest, or providing necessary goods (Razak et al., 2008).

${ }^{+}$Corresponding author 
As shown by the OECD research, proper corporate governance is essential to ensure a positive contribution of state-owned enterprises to the efficiency of the economy and its competitiveness. In many countries, state-owned enterprises are also the main providers of key public services, including services of public utility. This means that their activities have a major impact on citizens' everyday lives as well (OECD, 2015).

Moreover, numerous empirical studies (e.g., Grossi et al., 2015; Papenfuss \& Schmidt, 2015) point to the key role of corporate governance in the efficient management of state-owned enterprises and as a factor affecting the performance of companies (Linet al., 2009; Eforis, 2018; Muehlenkamp \& Holger, 2015; Rossieta, 2017).

\section{Review of corporate governance definitions}

Despite being widely used in both practice and theory of management, the concept of corporate governance evades clear definition. Although the predominant meaning of this concept refers to the mutual relationships between different groups involved in the functioning of an organisation (which include in particular shareholders, management, members of supervisory bodies, employees, suppliers and counterparties), various authors define its meaning differently, depending on the views expressed, in particular concerning the corporate environment, its objectives, its territory, or cultural diversity (Postuła, 2013). Today, corporate governance is analysed from the perspectives of different theoretical concepts, drawing on the achievements of many sciences. The interdisciplinary nature of corporate governance results in a wide array of definitions of the concept (Nedelchev, 2018). Table 1 presents some selected definitions of corporate governance proposed by researchers.

A review of the definitions of corporate governance shows that there is no single uniform definition. Different authors define its meaning in different ways, depending on the views expressed, in particular on the corporation's environment, its goals, the territory of functioning, or cultural diversity. The definition of corporate governance also depends on the theoretical approach used. Corporate governance can be referred exclusively to shareholders' interests and their relationship with management (agency theory approach) or to all interested groups (stakeholder theory). Some of the definitions present the matter in a very broad and general manner (Cadbury, 1999; Monks \& Minow, 1996). Other concepts emphasise shareholder rights in the company (Gospel \& Pendleton, 2003; Krzysztofek, 2012), and others also see the aspect of the company's stakeholders and its relations with the surrounding environment (Iwu-Egwuonwu, 2010; Zalega, 2000). The remaining concepts represent a compromise.

Table 1. Selected definitions of corporate governance

\begin{tabular}{|c|c|c|}
\hline No. & Author & Definition of corporate governance \\
\hline 1 & Monks and Minow (1996) & Maximising wealth creation in a way that does not burden others or society as a whole with undue costs. \\
\hline 2 & Zingales (1998) & $\begin{array}{l}\text { A system of restrictions that determine the creation of added value by the corporation and its allocation be- } \\
\text { tween its stakeholders. }\end{array}$ \\
\hline 3 & Cadbury (1999) & A system through which companies are managed and controlled at the same time. \\
\hline 4 & Zalega (2000) & $\begin{array}{l}\text { Control and supervision over a corporation, exercised not only by the appropriate statutory organs of the } \\
\text { company, but also by other groups interested in the firm or having an interest in its functioning. }\end{array}$ \\
\hline 5 & Gospel and Pendleton (2003) & $\begin{array}{l}\text { Corporate governance focuses on who controls the company, in whose interest it is managed, and on the way } \\
\text { in which the control is conducted. }\end{array}$ \\
\hline 6 & Jeżak and Bohdanowicz (2004) & $\begin{array}{l}\text { Ways of resolving conflicts between different groups that influence the management of the company, shaping } \\
\text { its strategies and its behaviour on capital markets, goods, and services markets, and the job market. }\end{array}$ \\
\hline 7 & Ayuso and Argandoña (2007) & $\begin{array}{l}\text { A system in which organisations are run and controlled and which defines the distribution of rights and ob- } \\
\text { ligations between shareholders and managers, as well as the rules and procedures for decision making in } \\
\text { corporate matters. In a broader sense, corporate governance also includes relations with other stakeholders, } \\
\text { both internal (e.g., employees) and external (e.g., customers, suppliers). }\end{array}$ \\
\hline 8 & Gök (2009) & $\begin{array}{l}\text { A set of principles that shape the behaviour of and exert pressure on managers to fulfil the promises given to } \\
\text { stakeholders, in particular to shareholders. }\end{array}$ \\
\hline 9 & Iwu-Egwuonwu (2010) & $\begin{array}{l}\text { A system in which corporations are managed and regulated to increase shareholder value and meet the } \\
\text { expectations of other stakeholders. }\end{array}$ \\
\hline 10 & Krzysztofek (2012) & $\begin{array}{l}\text { A mechanism used to control and coordinate the behaviour of shareholders who work with management to } \\
\text { effectively perform the company's tasks. }\end{array}$ \\
\hline 11 & OECD (2004) & $\begin{array}{l}\text { Concerns the relationship between the management and supervisory bodies of companies, their partners and } \\
\text { shareholders, and other shareholders (entities with an interest in the company's activities) and determines } \\
\text { the structure through which the company's objectives are set, the means of achieving these objectives, and } \\
\text { the means of keeping track of the company's performance. }\end{array}$ \\
\hline
\end{tabular}


The universal definition proposed by the OECD is commonly used by researchers. In view of the subject matter and objectives of this study, it was assumed that this definition will also be the most appropriate for the consideration of corporate governance in state-owned companies.

As a consequence of this decision, to ensure the consistency of terminology, it was assumed that it would be reasonable to use the definition proposed by the OECD to determine the meaning of a state-owned enterprise. OECD considers a stateowned enterprise to be "an economic entity in which the state has a full, majority or significant (i.e., that ensures impact on key decisions) share in the votes" (OECD, 2015).

\section{Corporate governance in state-owned enterprises as a separate field of corporate governance issue}

Corporate governance concerns many problems of contemporary corporations and is a dynamically developing discipline of organisation and management science of significant practical importance. Worldwide research on corporate governance describes this subject mainly in private companies. However, corporate governance is also an important and actual problem in companies owned by the state. At the same time, due to the separation of private companies and state-owned companies, corporate governance of enterprises owned by the state is considered a separate field of corporate governance issues, and state ownership determines the model of corporate governance in such entities (Postuła, 2013).

\section{RESEARCH OBJECTIVES AND HYPOTHESES}

Despite the high importance of state-owned enterprises for the development of global GDP and the quality of provided public services, research on corporate governance in state-owned enterprises is not widely represented in the world literature (Ciolomic \& Beleiu, 2020; Grossi et al., 2015).

This article proposes a bibliographic analysis of the existing scientific work on corporate governance in state-owned enterprises. The aim of the analysis is to systematise the scientific output in this field, to demonstrate the scale of interest in this subject among researchers, and to indicate the predominant directions of research, taking into account their geographical origin.

The following research hypotheses were formulated to achieve the objectives pursued:

$\mathrm{H} 1$ : Research on corporate governance in state-owned enterprises is not widely represented in global research.

$\mathrm{H} 2$ : There is a geographical variation in the dominant directions of research on corporate governance in state-owned enterprises.

In recent times, subject matter similar to that proposed in this article has been undertaken primarily by European researchers. Their research provides an overview of literature in the various aspects of the activities of state-owned enterprises. Examples of research include challenges related to self-regulatory techniques in the context of contemporary changes (Ciolomic \& Beleiu, 2020), orientation of public enterprises toward entrepreneurship (Tremml, 2019), the role of state enterprises as instruments of innovation policy (Tõnurist \& Karo, 2016), and comparison of performance between state and private companies (Varcholova \& Beslerova, 2013).

However, the research just mentioned is not a systematic literature review, directly dedicated to the issues of corporate governance in state-owned enterprises. This allows us to presume that the subject proposed in this article will enrich the current state of research on this issue.

\section{METHOD}

To compile an inventory of existing research work on corporate governance issues in state-owned enterprises, the full-text EBSCO Business Source Ultimate database and the Google Scholar database (as an auxiliary source for citation analysis) were used. To assemble an interesting collection of publications as the first step of the search, the following keyword corporate governance was used as a selection criterion. Using only this marker, a total of 18,641 scientific publications were obtained. Due to the size of the collection, which does not provide an opportunity for a reliable analysis, and also because of the need to separate articles on corporate governance issues in state-owned enterprises from the collection, another search was carried out in which, in addition to corporate governance, another keyword was used, namely state-owned, searched in the title or the abstract. The search restrictions were then applied to full-text, reviewed scientific publications in English. 
The analysis and selection carried out in this way reduced the number of items to an acceptable level from the perspective of a reliable analysis. The next step involved removing duplicates and misassigned items from the collection.

The database of publications thus obtained was then analysed for dynamics and the number of citations. Subsequently, to identify the dominant research themes in the different geographical regions, a frequency analysis was carried out.

\section{RESULTS}

The analysis carried out using the preceding methodology (completed on 23 February 2021) showed 323 items dedicated to researching corporate governance in state-owned enterprises. After further purging the collection of duplicates and misattributed items, a set of 262 peer-reviewed scientific publications on corporate governance issues in state-owned enterprises was obtained.

\section{Dynamics analysis}

An analysis of the research work dynamics was carried out in the next step (Figure 1). Analysing the number of publications over a given period allows one to assess the stage of development of a given research area. It is assumed that the number of publications follows a cycle, so after the start there is slow growth that accelerates, then stabilises at a given level, to finally drop (Czakon, 2011).

The analysed collection of publications includes items from 1982 to 2020 . The oldest research dates back to the early 1980s (Jones \& Goldberg, 1982; Monsen \& Walters, 1983). The analysis of the dynamics of the published works indicates a low level of interest in the subject among researchers in the years from 1982 to 2003. There is a significant increase in interest after 2003. However, the increase in importance of the topic of corporate governance that followed the 2008 financial crisis did not translate into a significant increase in research on corporate governance in state-owned enterprises. Significant research activity in this field is only clear between 2013 and 2019. Despite the increase in the number of publications during this period, the nominal number of research papers per year is relatively low, ranging from 12 in 2014 to 27 in 2018 . This points to a relatively small number of peer-reviewed research papers on corporate governance in state-owned enterprises. This effect is even more evident when one compares the number of research articles published at the same time on corporate governance issues in general.

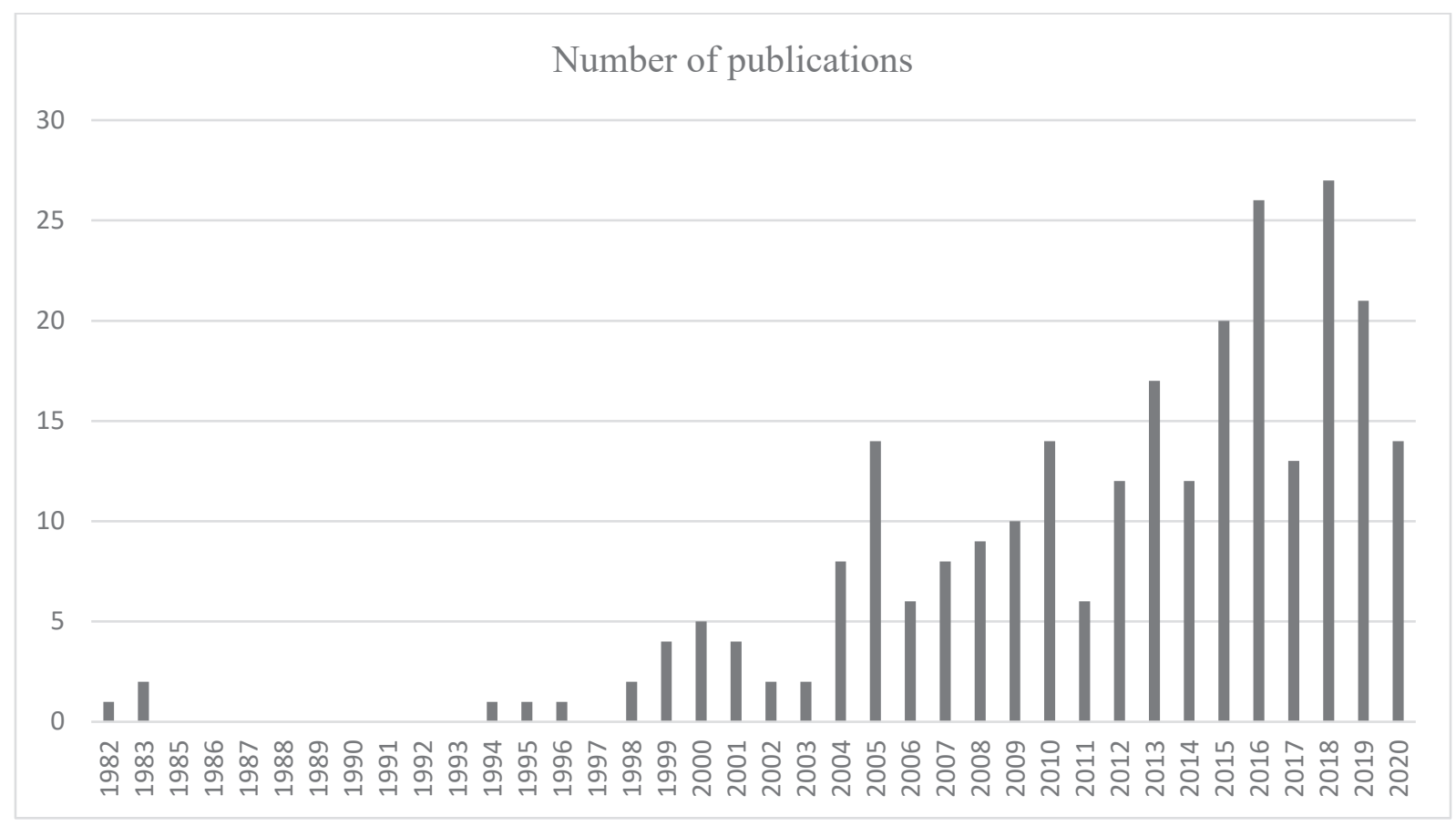

Figure 1. The number of scientific and research publications on corporate governance in state-owned enterprises from 1982 to 2020 . Research based on EBSCO (analysis completed on 23 February 2021). 
Table 2. Ranking of research articles with the highest number of citations

\begin{tabular}{|c|c|c|c|c|}
\hline No. & No. of citations & Position of an article & Journal & Impact factor (2019) \\
\hline 1 & 723 & $\begin{array}{l}\text { Jian, M., \& Wong, T. J. (2010). Propping through related party } \\
\text { transactions }\end{array}$ & $\begin{array}{l}\text { Review of Accounting } \\
\text { Studies }\end{array}$ & 2.600 \\
\hline 2 & 456 & $\begin{array}{l}\text { Ding, Y., Zhang, H., \& Zhang, J. (2007). Private vs state owner- } \\
\text { ship and earnings management: Evidence from Chinese listed } \\
\text { companies }\end{array}$ & $\begin{array}{l}\text { Corporate Governance: An } \\
\quad \text { International Review }\end{array}$ & 2.294 \\
\hline 3 & 437 & $\begin{array}{l}\text { Li, W., \& Zhang, R. (2010). Corporate social responsibility, owner- } \\
\text { ship structure, and political interference: Evidence from China }\end{array}$ & Journal of Business Ethics & 4.141 \\
\hline 4 & 416 & $\begin{array}{l}\text { Majumdar, S. K., \& Chhibber, P. (1999). Capital structure and } \\
\text { performance: Evidence from a transition economy on an aspect of } \\
\text { corporate governance }\end{array}$ & Public Choice & 1.035 \\
\hline 5 & 404 & $\begin{array}{l}\text { Terjesen, S., Aguilera, R., \& Lorenz, R. (2015). Legislating a } \\
\text { woman's seat on the board: Institutional factors driving gender } \\
\text { quotas for boards of directors }\end{array}$ & Journal of Business Ethics & 4.141 \\
\hline 6 & 392 & $\begin{array}{l}\text { Kato, T., \& Long, C. (2006). Executive compensation, firm perfor- } \\
\text { mance, and corporate governance in China: Evidence from firms } \\
\text { listed in the Shanghai and Shenzhen stock exchanges }\end{array}$ & $\begin{array}{l}\text { Economic Development \& } \\
\quad \text { Cultural Change }\end{array}$ & 1.860 \\
\hline 7 & 369 & $\begin{array}{l}\text { Peng, M. W., Tan, J., \& Tong, T. W. (2004). Ownership types and } \\
\text { strategic groups in an emerging economy }\end{array}$ & $\begin{array}{l}\text { Journal of Management } \\
\text { Studies (Wiley-Blackwell) }\end{array}$ & 4.888 \\
\hline 8 & 347 & $\begin{array}{l}\text { Lin, L.-W., \& Milhaupt, C. J. (2013). We are the (national) champi- } \\
\text { ons: Understanding the mechanisms of state capitalism in China }\end{array}$ & Stanford Law Review & 1.579 \\
\hline 9 & 332 & $\begin{array}{l}\text { Ramamurti, R. (2000). A multilevel model of privatization in emerg- } \\
\text { ing economies }\end{array}$ & $\begin{array}{l}\text { Academy of Management } \\
\text { Review }\end{array}$ & 8.413 \\
\hline 10 & 275 & $\begin{array}{l}\text { Chen, Q., Chen, X., Schipper, K., Xu, Y., \& Xue, J. (2012). The } \\
\text { sensitivity of corporate cash holdings to corporate governance }\end{array}$ & $\begin{array}{l}\text { Review of Financial } \\
\text { Studies }\end{array}$ & 4.649 \\
\hline
\end{tabular}

Note: Data collected from Google Scholar, 23 February 2021.

\section{Citation analysis}

To examine the relevance of the analysed research work for science, an analysis of the number of citations of the particular items was carried out (Table 2). The purpose of this procedure is to assess the significance of particular items for science and to single out from the collection those that are most important in the scientific discipline. This technique also allows us to isolate publications that have inspired many other researchers, laying the foundations for further research projects (Czakon, 2011). In the analysed collection, most items have a two-digit number of citations (99). Works with a one-digit number of citations (78) also make up a significant group. There are fewer items with a three-digit number of citations (31). Results are shown in Figure 2.

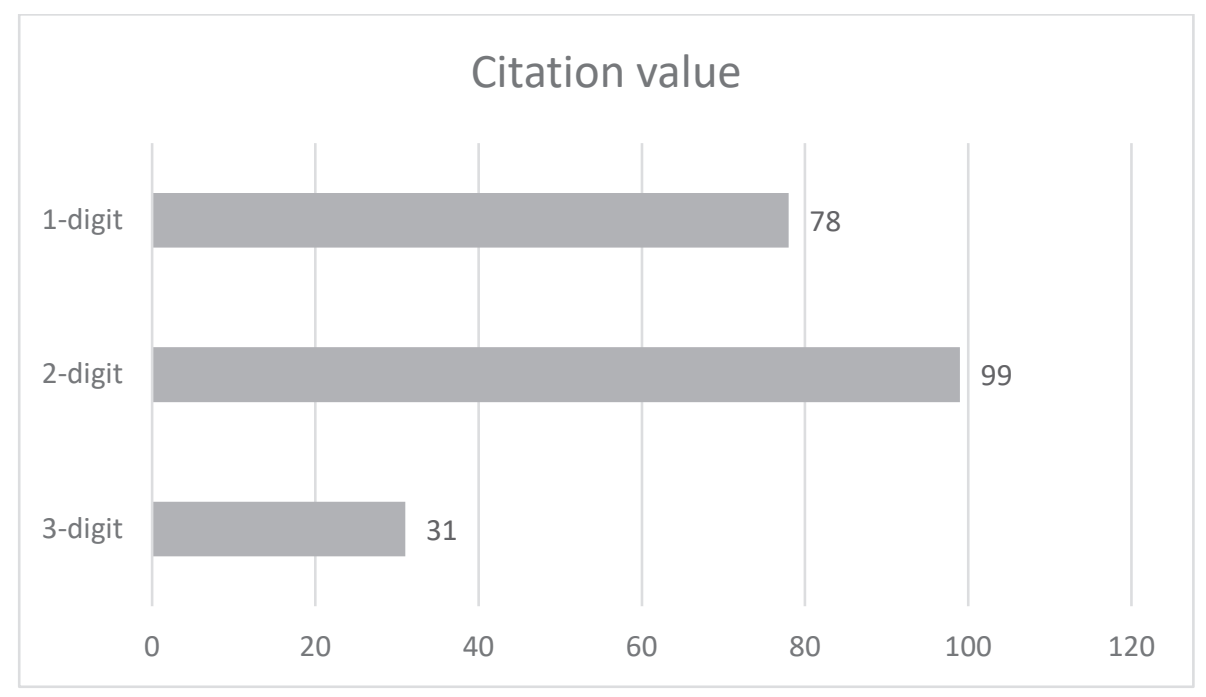

Figure 2. Breakdown of articles by the number of citations.

Note: Data collected from Google Scholar, 23 February 2021. 
A noticeable trend is that the most recent articles generally have not reached high levels of citations. An exception to this rule can be found in a few relatively new studies with three-digit numbers of citations Schwartz-Ziv (2017), Terjesen et al. (2015), Musacchio et al. (2015), and Grossi et al. (2015).

\section{Geographic distribution of research}

To examine the geographical distribution of the research conducted, the collection was divided according to the geographic region of origin. To ensure an adequate level of comparability of data, the results (Figure 3) are presented by continent, and, in the case of a larger number of papers, they are also broken down by country. Due to the large number of papers published in China, the Chinese studies are presented separately.

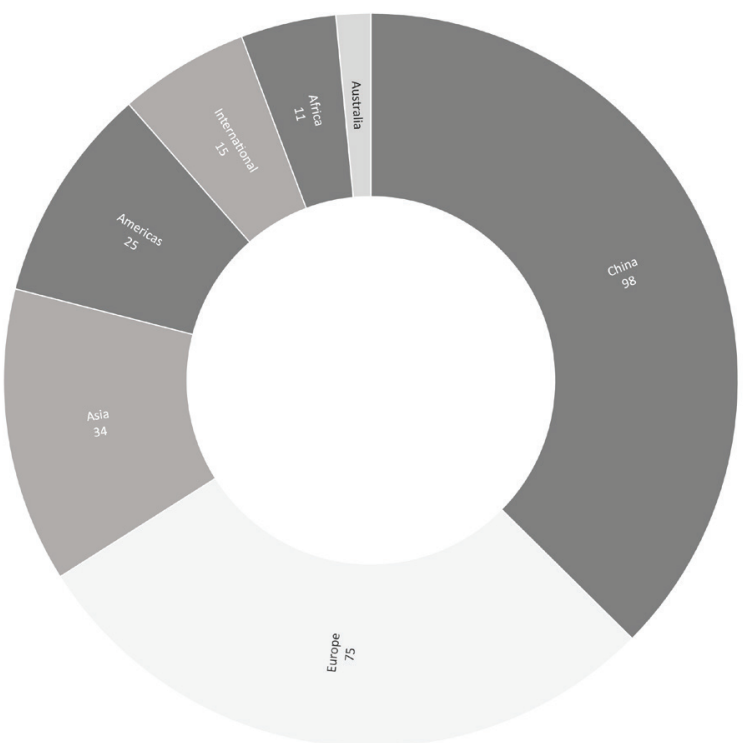

Figure 3. Geographical distribution of research on corporate governance in state-owned enterprises. Note: Research based on the EBSCO database.

The analysis shows that in the years from 1982 to 2020, research on corporate governance in state-owned enterprises was conducted in 41 countries worldwide. The largest number of studies were conducted in China, with 96 . This was followed by Europe with 75, 36 of which were from Western Europe, with the highest number in the United Kingdom (9); and 43 from Central and Eastern Europe, with Romania on top (11). In the rest of Asia (excluding China), the number of papers was 31 . In North and South America (United States, Canada, and Brazil), the number of articles was 25, out of which the United States accounted for 14. Africa accounted for 9 studies, and Australia was accounted for 4. Of the items examined, 15 were international studies. Figure 3 shows that China dominates globally in research on corporate governance in state-owned enterprises with $37 \%$ of the total number of research papers. However, given the huge number of state-owned enterprises in that country (more than $51,000)$, this figure does not seem to be significant. European research $(29 \%)$ came in second. This group is dominated by research conducted in Central and Eastern Europe. Despite the growing importance of state capital in Western European countries, the amount of research conducted there does not exceed that of Central and Eastern Europe. The next geographic area with a significant number of articles is Asia (excluding China), with $12 \%$. The small number of papers on the American continents (especially in the United States) can be explained by the small participation of the state sector in the economy of that country.

\section{Analysis of dominant research categories (general approach)}

To focus on the dominant categories and subjects of research on corporate governance in state-owned enterprises, frequency analysis was used (Czakon, 2011). To this end, the body of research papers (262 items) was analysed for the frequency of key concepts appearing in titles or abstracts of scientific articles. Results in the form of a word cloud are shown in Figure 4. 


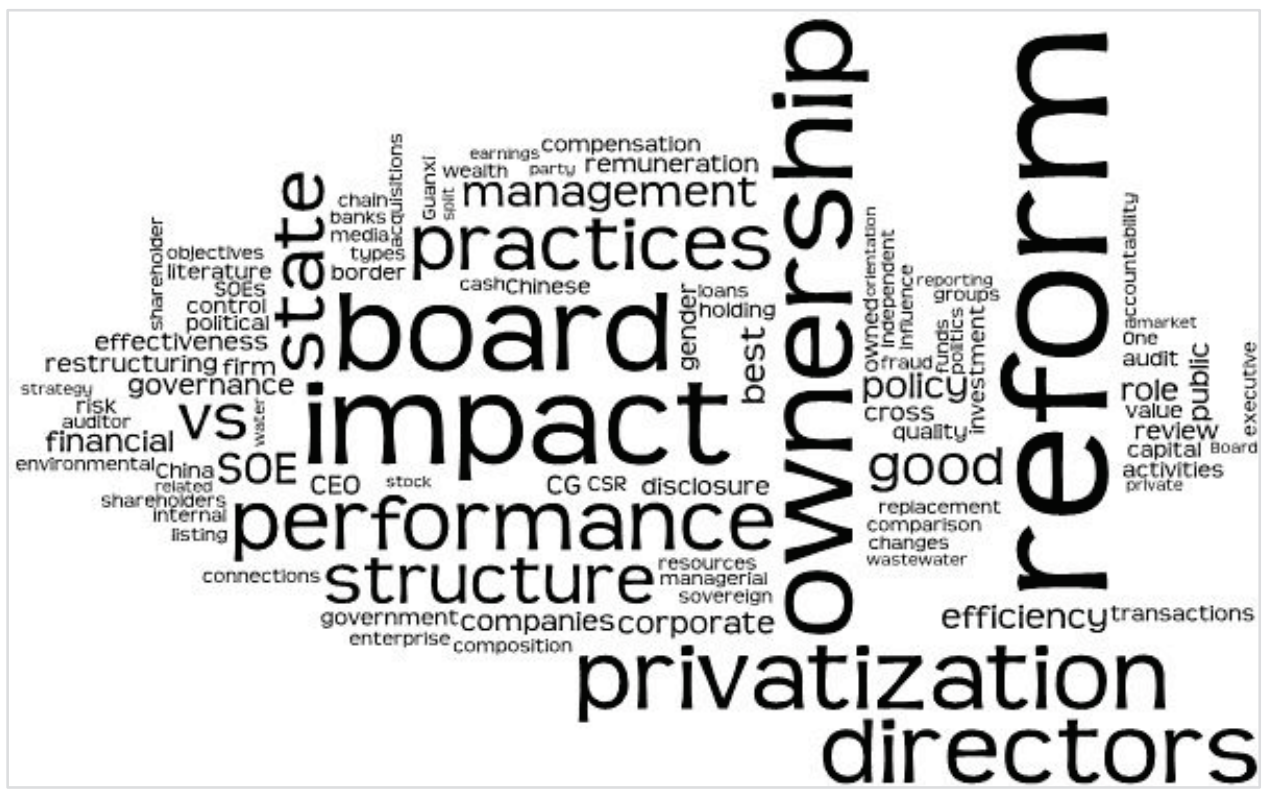

Figure 4. Word cloud for research on corporate governance in state-owned enterprises (general).

The frequency analysis of all the works included in the collection showed that matters concerning reforming corporate governance are the predominant category. This subject represents $(18 \%)$ of the total and is most prominently featured in Chinese research. Examples of the studies with the highest number of citations concern reforming the split shareholder structure (Firth et al., 2010), the impact of reforms and moving the patterns from Western economies into corporate governance (Wang, 2014), and corporate governance models reform proposal (Tam, 2000). This subject is also clearly outlined in Asian research (excluding China): a potential model for corporate governance reform in Singapore (Cheng-Han et al., 2015), analysis of the challenges facing Indonesian companies in applying corporate governance (Wicaksono, 2008), assessment of the transformation of the corporate governance system in Singapore (Yin Sam, 2007), and reform of the functioning of the Vietnamese banking system (Quang et al., 2004).

Another important group is research dedicated to the board of directors, its form, composition, and impact on the business, which made up $10 \%$ of the total number of studies. In this group, the dominant research comes from Asia. Examples of research subjects include activities of government (political) directors on the board of directors (Zhu \& Yoshikawa, 2016), the impact of the dual role of CEOs in corporate governance (Firth et al., 2014), activities of independent directors on the board and their impact on investor protection (Liu et al., 2016), a description of the concept of boards of directors in company groups (Yeo, 2013), and comparison of the functioning of the boards of directors of state-owned and private companies (Tong et al., 2015). Another important group is the privatisation of state-owned enterprises, which accounts for $10 \%$ of the total number of research papers. This trend is most strongly present in European research, with topics including comparative analysis of the privatisation paths of state assets in Russia and China (Buck et al., 2000), mass privatisation in Bulgaria (Miller, 2000), and the impact of privatisation on incentives for managers and on company performance (Cragg \& Dyck, 2003). In Asian research, topics include recommendations for the privatisation of state financial institutions (Majumdar \& Chhibber, 1999), multilevel privatisation models (Ramamurti, 2000), and impact of privatisation on the performance of companies in Vietnam (Loc et al., 2006).

The next significant group is research on the impact of corporate governance on company performance, making up $8.4 \%$ of the total number of papers. This trend is most prominently visible in Asian research (excluding China), with topics including analysing the relationship between debt levels in the capital structure and the performance of state-owned enterprises in India (Majumdar \& Chhibber, 1999), the impact of privatisation and changes in corporate governance on the performance of companies (Loc et al., 2006), and the impact of corporate governance and internal audits on the performance of companies in Indonesia (Octavia, 2013). This category of research is also visible in European research, with subjects like the analysis of ownership structure and its impact on the performance of companies in the hospitality industry (Cvelbar \& Mihalič, 2007), the impact of the concentration of ownership on the operational results of the acquiring companies (Boateng \& Brahma, 2017), and the impact of state ownership on the performance of listed companies (Bistrova \& Lace, 2010). 
The last identifiable subject group focuses on good practices of corporate governance in state-owned enterprises, with $7.6 \%$ of the total papers. This subject matter dominates among European researchers. Examples of paper topics are corporate social responsibility and ethical tax corporate governance (Hauptman \& Belak, 2015), positive effects of the implementation of corporate governance principles in Lithuanian state-owned enterprises (Jurkonis \& Petrusauskaitè, 2014), analysis of key corporate governance factors (Domokos et al., 2016), and implementation of good practises of corporate governance in Romania (Dumitraşcu et al., 2015).

\section{Analysis of dominant research categories (geographic approach)}

Due to the assumption that the trends prevailing in research on corporate governance in state-owned enterprises may vary according to their geographic origin, a frequency analysis was conducted, taking into account the geographic distribution criterion. The analysis was based on geographic regions with the highest number of research on corporate governance in state-owned enterprises (see Figure 2). Geographic regions as identified for the analysis were China, Europe, and Asia (excluding China).

\section{China}

The main trend in Chinese research is the issue of corporate governance reform and corporate governance in China (Figure 5). This subject matter is presented by about $20 \%$ of researchers in the collection. Another important group is the research devoted to shareholder ownership and state ownership as well as their impact on corporate governance. A large group of articles also include research on the functioning of boards of directors, and their shape, composition, and impact on the functioning of the company. Other noticeable trends concern privatisation issues, the impact of corporate governance on the performance and efficiency of companies, and the impact of policy on corporate governance. For the remainder of the research aspects, there is a significant fragmentation, making it impossible to identify another logical group of studies.

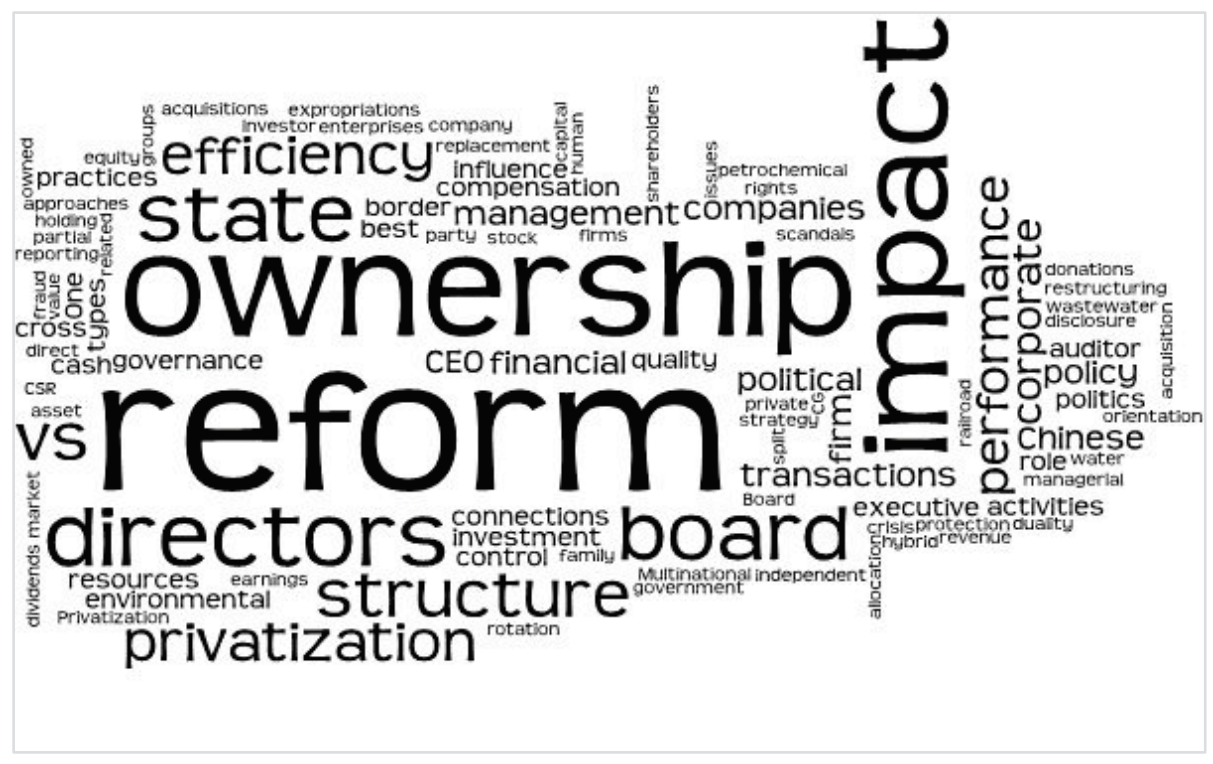

Figure 5. Word cloud for research on corporate governance in state-owned enterprises in China.

\section{Europe}

The issue of privatisation of state-owned enterprises, represented by around $17 \%$ of the total number of research papers, is clearly the dominant trend in European research (Figure 6). Another significant subject group is research on good practices and corporate governance. Another visible group of studies contains works on the impact of ownership structure (state-owned) on the performance of enterprises. Other distinctive subject groups focus on corporate governance reform issues and the composition and functioning of the board and board of directors. 


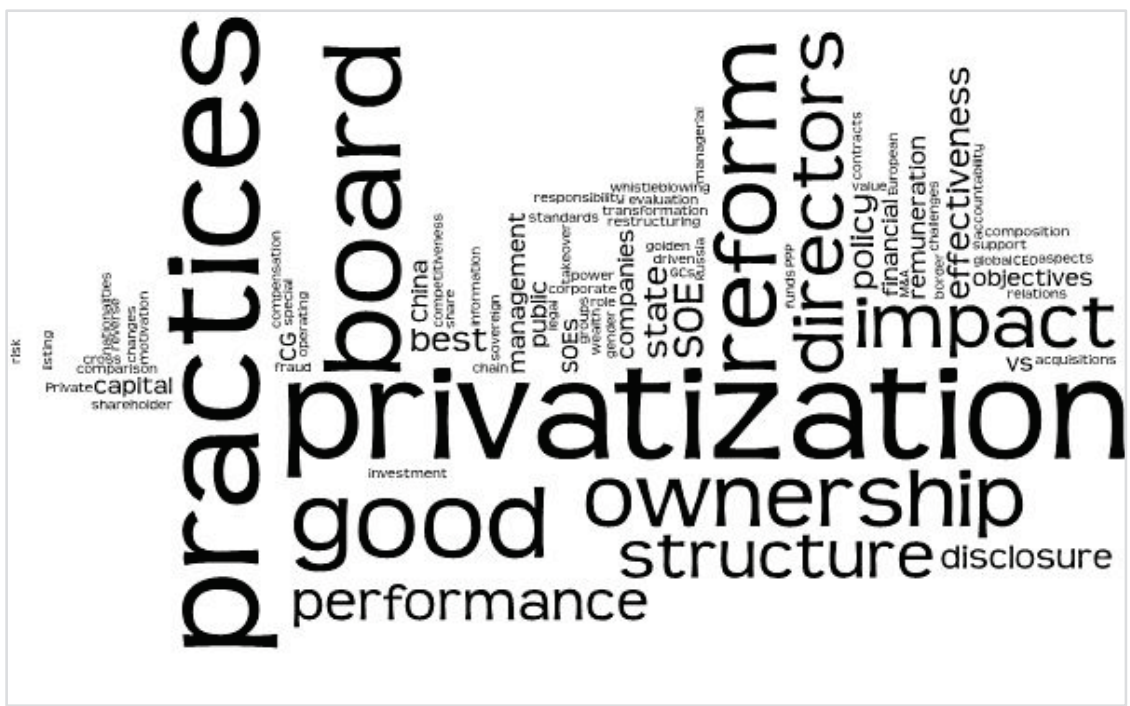

Figure 6. Word cloud for research on corporate governance in state-owned enterprises in Europe.

\section{Asia (excluding China)}

Research conducted on the Asian continent (excluding China) is clearly dominated by the issue of how corporate governance affects business performance, which accounts for $30 \%$ of all papers (Figure 7). Another important topic of research is the reform of corporate governance, as well as privatisation. Yet another common subject is the impact of the ownership structure on the performance of companies. The remaining subjects are fragmented and do not allow for logical grouping into a further category.

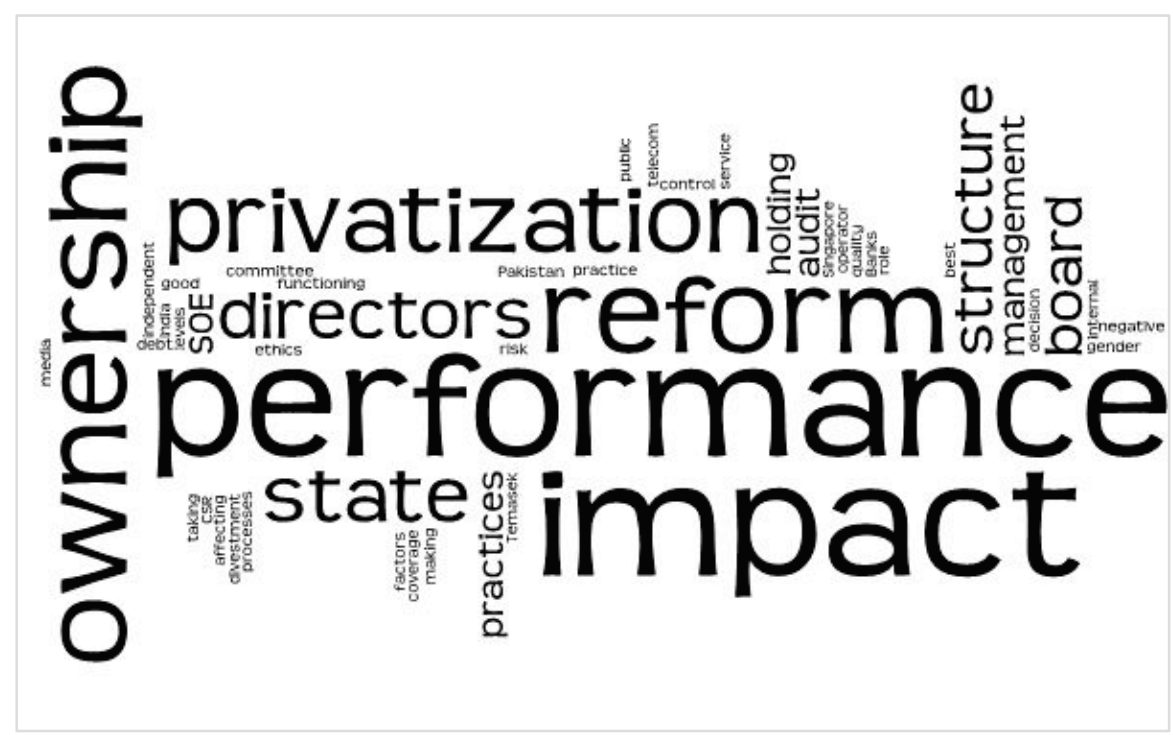

Figure 7. Word cloud for research on corporate governance in state-owned enterprises in Asia (excluding China). 


\section{Comprehensive comparison}

Table 3 provides a comprehensive comparison of the dominant research categories from a geographic point of view using a frequency analysis. The analysis was based on geographic regions with the highest number of research studies on corporate governance in state-owned enterprises (see Figure 2).

Table 3 presents a comparison of dominant research categories in research articles about corporate governance in state-owned enterprises in particular geographic areas. The data source for the preceding analysis is the results of the frequency analysis carried out (Figures 5-7). The dominant categories are presented by means of frequency levels. A ranking of 1 denotes the most common subject of research and 5 indicates the least common subject of research. For Asian studies at frequency level 5 , it was not possible to single out another subject group due to a significant fragmentation of research.

According to Table 3 , in regions with the highest number of research articles into corporate governance in state-owned enterprises, the dominant research categories differ from each other. In Chinese research, the subject of corporate governance reform clearly dominates. European researchers are most likely to explore the issues of privatisation of state-owned enterprises and its impact on corporate governance. In Asian research, in turn, research focusing on the impact of corporate governance on business performance is clearly dominant. There is also a marked lack of consistency in the dominant research topics across geographic regions, at the same frequency level.

Table 3. Comparison of dominant research categories in research on corporate governance in state-owned enterprises from the point of view of geography

\begin{tabular}{|c|c|c|c|}
\hline \multicolumn{4}{|c|}{ Dominant categories (research groups) } \\
\hline $\begin{array}{l}\text { Frequency levels } \\
\qquad(1-5)\end{array}$ & China & Europe & $\begin{array}{c}\text { Asia } \\
\text { (excluding China) }\end{array}$ \\
\hline 1 & Reform of corporate governance & Privatisation & $\begin{array}{l}\text { The impact of corporate governance on } \\
\text { business performance }\end{array}$ \\
\hline 2 & $\begin{array}{l}\text { The impact of state ownership on } \\
\text { corporate governance }\end{array}$ & $\begin{array}{l}\text { Good practices in corporate } \\
\text { governance }\end{array}$ & Reform of corporate governance \\
\hline 3 & $\begin{array}{l}\text { The functioning of the board of } \\
\text { directors }\end{array}$ & $\begin{array}{c}\text { The impact of ownership structure on } \\
\text { results }\end{array}$ & Privatisation \\
\hline 4 & Privatisation & Reform of corporate governance & $\begin{array}{l}\text { The impact of ownership structure on } \\
\text { results }\end{array}$ \\
\hline 5 & $\begin{array}{c}\text { The impact of corporate governance on } \\
\text { business performance }\end{array}$ & $\begin{array}{l}\text { The functioning of the board and the } \\
\text { board of directors }\end{array}$ & None \\
\hline
\end{tabular}

\section{CONCLUSIONS}

The purpose of this study was to systematise the scientific output on corporate governance in state-owned enterprises, to show the scale of interest among researchers in this subject, and to present dominant research trends, including research interests, taking into account geographic distribution.

The analyses conducted demonstrated that corporate governance in state-owned enterprises is not widely represented in research. Thus categorised, the body of research articles in this field is insignificant in relation to the number of state-owned enterprises operating worldwide and their importance for the global economy. China is a strong leader in the number of published papers, but given the number of state-owned enterprises operating in China, this value appears to be relatively small. The frequency analysis showed that the main focuses in research were (1) reform of corporate governance, (2) functioning of the board of directors (form, composition, and impact on the business), and (3) privatisation of state-owned enterprises. Research by dominant research groups from the point of view of geography has shown that there is a clear variation in the dominant direction of research on corporate governance in state-owned enterprises, which is an indication of the different 
interests of researchers in different geographic areas. Analysing the factors underlying the differentiation just described might provide an incentive for further empirical research in this area.

When analysing the results of this study, account should be taken of the methodological limitations applied by the author. First, this bibliographical study was conducted on the basis of the resources of EBSCO Business Source Ultimate, assuming that the database should include all relevant items for the study group of publications. Second, the analysis was limited to full-text, peer-reviewed scientific articles in English. Finally, the analysis was performed using keywords to test their presence in the title or abstract. It cannot be ruled out that there are works on the subject under discussion that, because of their failure to meet these criteria, were not covered by this study. However, this should not have a significant impact on the results of this study.

\section{REFERENCES}

Ayuso, S., \& Argandoña, A. (2007). Chair of Corporate Social Responsibility and Corporate Governance La Caixa. Working Paper, $701,1$.

Bistrova, J., \& Lace, N. (2010). Ownership structure in Cee Companies and its influence on stock performance. Economics \& Management, $15,880-885$.

Boateng, A., Bi, X., \& Brahma, S. (2017). The impact of firm ownership, board monitoring on operating performance of Chinese mergers and acquisitions. Review of Quantitative Finance \& Accounting, 49(4), 925-948.

Buck, T., Filatotchev, I., Nolan, P., \& Wright, M. (2000). Different paths to economic reform in Russia and China: Causes and consequences. Journal of World Business, 35(4), 379.

Cadbury, A. (1999). What are the trends in corporate governance? How will they impact your company? Long Range Planning, 1, 14-16.

Ciolomic, I.-A., \& Beleiu, I. N. (2020). State-owned enterprises in the context of contemporary transformations. Review of International Comparative Management/Revista de Management Comparat International, 21(2), 177-187.

Cragg, M. I., \& Dyck, I. J. A. (2003). Privatization and management incentives: Evidence from the United Kingdom. Journal of Law, Economics \& Organization, 19(1), 176.

Cvelbar, L. K., \& Mihalič, T. (2007). Ownership structure as a corporate governance mechanism in Slovenian hotels. Economic Trends \& Economic Policy, 17(112), 26-51.

Czakon, W. (2011). Metodyka systematycznego przeglądu literatury (Methodology for a systematic literature review). Przegląd Organizacji, 3 , 57-61.

Ding, Y., Zhang, H., \& Zhang, J. (2007). Private vs state ownership and earnings management: Evidence from Chinese listed companies. Corporate Governance: An International Review, 15(2), 223-238.

Domokos, L., Várpalotai, V., Jakovác, K., Németh, E., Makkai, M., \& Horváth, M. (2016). Renewal of public management. Public Finance Quarterly, 61(2), 178-198.

Dumitraşcu, M., Feleagă, L., \& Feleagă, N. (2015). The practical implementation of corporate governance principles for Romanian state owned enterprises. Audit Financiar, 13(121), 91-99.

Eforis, C. (2018). Corporate governance, state ownership and firm performance: An empirical study of state-owned enterprises in Indonesia. Accounting \& Finance Review (AFR), 3(1), 26-32.

Firth, M., Lin, C., \& Zou, H. (2010). Friend or foe? The role of state and mutual fund ownership in the split share structure reform in China. Journal of Financial \& Quantitative Analysis, 45(3), 685-706.

Firth, M., Wong, S., \& Yang, Y. (2014). The double-edged sword of CEO/chairperson duality in corporatized state-owned firms: Evidence from top management turnover in China. Journal of Management \& Governance, 18(1), 207-244.

Gök, T. (2009). Corporate governance in an era of turmoil. Smart Business Network Inc., 1.

Gospel, H., \& Pendleton, A. (2003). Finance, corporate governance and the management of labour: A conceptual and comparative analysis. British Journal of Industrial Relations, 41(1), 560.

Grossi, G., Papenfuß, U., \& Tremblay, M.-S. (2015). Corporate governance and accountability of state-owned enterprises: Relevance for science and society and interdisciplinary research perspectives. International Journal of Public Sector Management, 28(4-5), 274-285.

Hauptman, L., \& Belak, J. (2015). Ethical tax corporate governance of state-owned enterprises. Systems Research \& Behavioral Science, 32(2), 183-189.

International Monetary Fund. (2020). State-owned enterprises in the time of COVID-19. https://blogs.imf.org/2020/05/07/state-owned-enterprises-in-the-time-of-covid-19

Iwu-Egwuonwu, R. C. (2010). Some empirical literature evidence on the effects of independent directors on firm performance. Journal of Economics and International Finance, 2(9), 190. 
Jeżak, J., \& Bohdanowicz, L. (2004). Nadzór korporacyjny (w:) Leksykon zarządzania (Corporate governance in: Lexicon of management), red. M. Romanowska, Difin,Warszawa.

Jian, M., \& Wong, T. J. (2010). Propping through related party transactions. Review of Accounting Studies, 15(1), 70-105.

Jones, T. M., \& Goldberg, L. D. (1982). Governing the large corporation: More arguments for public directors. Academy of Management Review, $7(4), 603-611$.

Jurkonis, L., \& Petrusauskaitè, D. (2014). Effects of corporate governance on management efficiency of Lithuanian state-owned enterprises. Ekonomika/Economics, 93(2), 77-97.

Kato, T., \& Long, C. (2006). Executive compensation, firm performance, and corporate governance in China: Evidence from firms listed in the Shanghai and Shenzhen stock exchanges. Economic Development \& Cultural Change, 54(4), 945-983.

Krzysztofek, A. (2012). Teoretyczne aspekty funkcjonowania nadzoru korporacyjnego (Theoretical aspects of corporate governance). Zarządzanie i Finanse, 10(4), 331-347.

Li, W., \& Zhang, R. (2010). Corporate social responsibility, ownership structure, and political interference: Evidence from China. Journal of Business Ethics, 96(4), 631-645.

Lin, C., Ma, Y., \& Su, D. (2009). Corporate governance and firm efficiency: Evidence from China's publicly listed firms. Managerial \& Decision Economics, 30(3), 193-209.

Lin, L.-W., \& Milhaupt, C. J. (2013). We are the (national) champions: Understanding the mechanisms of state capitalism in China. Stanford Law Review, 65(4), 697-759.

Liu, H., Wang, H., \& Wu, L. (2016). Removing vacant chairs: Does independent directors' attendance at board meetings matter? Journal of Business Ethics, 133(2), 375-393.

Loc, T. D., Lanjouw, G., \& Lensink, R. (2006). The impact of privatization on firm performance in a transition economy. Economics of Transition, 14(2), 349-389.

Majumdar, S. K., \& Chhibber, P. (1999). Capital structure and performance: Evidence from a transition economy on an aspect of corporate governance. Public Choice, 98(3-4), 287-305.

Miller, J. B. (2000). The first wave of mass privatization in Bulgaria and its immediate aftermath. Economics of Transition, 8(1), 225.

Monks, R.A.G., \& Minow, N. (1996). Watching the watchers: Corporate governance for the 21st century. Cambridge University Press.

Monsen, R. J., \& Walters, K. D. (1983). Who should control nationalized companies? California Management Review, 25(4), 27-36.

Muehlenkamp, H. (2015). From state to market revisited: A reassessment of the empirical evidence on the efficiency of public (and privatelyowned) enterprises. Annals of Public and Cooperative Economics, 86(4), 535-557. https://www.voewg.at/wp-content/M\%C3\%BC-2015_ From-State-to-Market-Revisited.pdf

Musacchio, A., Lazzarini, S. G., \& Aguilera, R. V. (2015). New varieties of state capitalism: Strategic and governance implications. Academy of Management Perspectives, 29(1), 115-131.

Nedelchev, M. (2018). Bibliometric review of corporate governance theories and methods. Economic Studies, 27(4), $126-145$.

Octavia, E. (2013). The effects of implementation on internal audit and good corporate governance in corporate performance. Journal of Global Business \& Economics, 6(1), 77-87

Organisation for Economic Co-operation and Development. (2004). OECD principles of corporate governance. Retrieved April 22, 2021, from https://www.oecd.org/daf/ca/corporategovernanceprinciples/34656740.pdf

Organisation for Economic Co-operation and Development. (2015). OECD guidelines on corporate governance of state-owned enterprises (2015 ed.). OECD Publishing. https://doi.org/10.1787/9789264244160-en

Organisation for Economic Co-operation and Development. (2017). The size and sectoral distribution of state-owned enterprises. OEDC Publishing. https://doi.org/10.1787/9789264280663-en

Papenfuss, U., \& Schmidt, C. (2015). Determinants of manager pay in German state-owned enterprises and international public policy implications: 3-years study for sectors, performance and gender (Working paper). University of Leipzig. Retrieved March 7, 2021, from http://hdl. handle.net/10419/107708

Pekao. (2020). Siła napędowa czy hamulec rozwoju. Rola spółek Skarbu Państwa w kontekście kryzysu COVID 19. Retrieved February 23, 2021, from https://media.pekao.com.pl/pr/556248/rola-spolek-skarbu-panstwa-w-dobie-kryzysu-covid-19-najnowszy-raport-banku-pekaos-a?rss=true

Peng, M. W., Tan, J., \& Tong, T. W. (2004). Ownership types and strategic groups in an emerging economy. Journal of Management Studies, 41(7), 1105-1129.

Postuła, I. (2013). Nadzór korporacyjny w spółkach Skarbu Państwa (Corporate governance in state-owned companies). Wolters Kluwer.

Quang, T. N., Dang, N. T., Ha, D. T., \& Dzung, V. (2004). Vietnam. International Financial Law Review, 89-92.

Ramamurti, R. (2000). A multilevel model of privatization in emerging economies. Academy of Management Review, 25(3), 525-550. 
Razak, N. H., Ahmad, R., \& Aliahmed, H. J. (2008). Government ownership and performance: An analysis of listed companies in Malaysia. Corporate Ownership \& Control, 6(2), 434-442.

Rossieta, H. (2017). Good governance mechanism, agency problems and privatized SOEs performance: Empirical evidences from Indonesian stock exchange. International Journal of Economics \& Management, 11(Suppl. 2), 287-307.

Schwartz-Ziv, M. (2017). Gender and Board Activeness: The Role of a Critical Mass. Journal of Financial \& Quantitative Analysis, 52(2), $751-780$

Tam, O. K. (2000). Models of corporate governance for Chinese companies. Corporate Governance: An International Review, 8(1), 52.

Tan, C.-H., Puchniak, D. W., \& Varonil, U. (2015). State-owned enterprises in Singapore: Historical insights into a potential model for reform. Columbia Journal of Asian Law, 28(2), 61-97.

Terjesen, S., Aguilera, R., \& Lorenz, R. (2015). Legislating a woman's seat on the board: Institutional factors driving gender quotas for boards of directors. Journal of Business Ethics, 128(2), 233-251.

Tong, S., Junarsin, E., \& Li, C. (2015). A comparative study of Chinese SOE firm's boards and private firm's boards. Annals of Economics \& Finance, 16(2), 291-314.

Tõnurist, P., \& Karo, E. (2016). State owned enterprises as instruments of innovation policy. Annals of Public \& Cooperative Economics, 87(4), 623-648. https://doi.org/10.1111/apce.12126

Tremml, T. (2019). Linking two worlds? Entrepreneurial orientation in public enterprises: A systematic review and research agenda. Annals of Public \& Cooperative Economics, 90(1), 25-51.

Varcholova, T., \& Beslerova, S. (2013). Ownership structure and company performance: Research and literature review. Financial Internet Quarterly "e-Finanse," 9(2), 24-33.

Wang, J. (2014). The political logic of corporate governance in China's state-owned enterprises. Cornell International Law Journal, 47(3), 634-669.

Wicaksono, A. (2008). Indonesian state-owned enterprises. In Southeast Asian Affairs 2008, ed. Singh, D., Than, T., ISEAS Publishing, $146-167$.

Yeo, Y. (2013). Contextualizing corporate governance: The case of China's central state enterprise groups. Journal of Contemporary China, 22(81), 460-475.

Yin Sam, C. (2007). Corporate governance reforms in the post-1997 Asian crisis: Is there really a convergence to the Anglo-American model? Global Economic Review, 36(3), 267-285.

Zalega, K. (2000). Spór o pojęcie corporate governance (Dispute over the concept of corporate governance). Organizacja $i$ Kierowanie, 3 , 83-98.

Zhu, H., \& Yoshikawa, T. (2016). Contingent value of director identification: The role of government directors in monitoring and resource provision in an emerging economy. Strategic Management Journal, 37(8), 1787-1807.

Zingales, L. (1998). Corporate governance. In The new Palgrave dictionary of economics and the law ed. Newman, P., (p. 499). Palgrave Macmillan. 